\title{
Limit Base Erosion via Interest Deduction and Others
}

\author{
Emilio Cencerrado Millán \& María Teresa Soler Roch*
}

\begin{abstract}
BEPS Action 4 focuses on excessive deductible interest and other financial payments, thus recommending the design of rules in order to prevent base erosion through the use of interest payments and double non-taxation both from an inbound and an outbound perspective.

This article deals with some relevant questions related to this topic, such as the grounds for justification, the limitations based on classification and the financial expenses related to exempted income, with special reference to some relevant experiences and case law in the European Union. Taking into account that some tax jurisdictions have enacted provisions in this respect, the authors also analyse some comparative examples as well as the main concerns related to legal principles and taxpayers' position and Tax Treaty issues.
\end{abstract}

\section{INTRODUCTION. BEPS ACTION 4: ISSUES AND PERSPECTIVES}

The main issue expressed in Action 4 focuses on 'excessive deductible payments such as interest and other financial payments' and the main goal is preventing from the risk of double non-taxation. The meaning of 'excessive' interest remains to some extent unclear: 'excessive' related to what? Who decides what and in which circumstances is the interest 'excessive'?

The concern about double non-taxation is not new. IFA dealt with this subject in the Vienna Congress (2004), ${ }^{1}$ but BEPS has enhanced this concept which is meant to be a new international tax standard and, as such, expressly included in the Preamble of the OECD MC. ${ }^{2}$ But it is obvious that, in the present situation, double non-taxation is in most cases the result of mismatches resulting from domestic legislation in the residence and the source country, combined with the allocation rules in the Tax Treaties and it will be hypocrite or naif to pretend that double non-taxation is always the intention and result of 'aggressive' tax planning. Tax policy measures and moreover, harmful tax competition have also very much to do with this problem. ${ }^{3}$

Regarding its justification, Action 4 refers to base erosion and profit shifting caused by the deduction of interest in two different perspectives:

First, the inbound perspective: 'Lending from a related entity that benefits from a low-tax regime, to create excessive deductions for the issuer without a corresponding interest income inclusion by the holder.'

Three main features arise from this perspective, according to its wording: it refers only to intra-group transactions ('related entity'); the problem is the effect of aggressive tax planning (intention: 'to create'); the result is double non-taxation ('without the corresponding income inclusion'). But there are some pending questions, such as: is low taxation also included? The bilateral picture seems to deal with the mismatch arising from domestic legislation, although it may also affect Tax Treaty issues. Transfer pricing rules may also be affected, although this perspective does not deal with arm's length but with

\section{Notes}

Tax Law Professors, Universidad de Alicante.

See: 'Double non-taxation' (General Report byM.Lang) Cahiers de Droit Fiscal International, vol.89a. International Fiscal Association 2004. Published by Sdu Fiscale\&Financiële Uitgevers.

The recent document on Action 6, about the 'Clarification that tax treaties are not intended to be used to generate double non taxation', proposes the addition in the Preamble of the Convention, of the following wording: '(State A) and (State B) Desiring to further develop their economic relationship and to enhance their cooperation in tax matters Intending to conclude a Convention for the elimination of double taxation with respect to taxes on income and on capital without creating opportunities for double non-taxation or reduced taxation through tax evasion or avoidance (including through treaty-shopping arrangements aimed at obtaining reliefs provided in this Convention for the indirect benefit of residents of third States)'. See: OECD/G20 Base Erosion and Profit Shifting Project 'Preventing the Granting of Treaty Benefits in Inappropriate Circumstances' (Action 6: 2014 Deliverable), Section B.

As it has been pointed out in this respect 'MNE tax avoidance is just the flipside of harmful tax competition' H. Ault, W. Schön \& S.E. Say 'Base Erosion and Profit Shifting: a Roadmap for Reform' Bulletin for International Taxation vol. 68 issues 6/7, 2014. IBFD. 
double non-taxation. Anyhow, we must bear in mind that this is only soft-law, so interpretation shall focus on the future provisions implementing this Action.

Second, the outbound perspective: 'Use debt to finance the production of exempted or deferred income thereby claiming a current deduction for interest expense while deferring or exempting the related income'.

Regarding this perspective, some main features arise from the wording: the reference to 'exempted or deferred income' means that the result will either be double nontaxation or a time mismatch; it does not refer to related parties; the reference to 'related income' has a broader meaning including not only interest but any other kind of income (i.e., dividends), as long as this income has been obtained because of debt financing; the intentional element of aggressive tax planning ('use debt') is unclear. Also in this case, interpretation shall focus in the future provisions implementing this Action.

In order to counteract both situations, the Action proposed is:

Develop recommendation regarding best practices in the design of rules to prevent base erosion through the use of interest expense, i.e. through the use of relatedparty and third-party debt to achieve excessive interest deduction or to finance the production of exempt or deferred income.

It seems obvious that such rules should be implemented through domestic legislation taking into account both perspectives (inbound and out bound), although the wording of the proposal shows an unclear mixture of both perspectives; the type of taxpayers (related or third parties) as well as the objective of avoiding double non-taxation should also be considered. ${ }^{4}$ Moreover, 'prevent base erosion' also means reinforce corporate tax revenue, which indicates that the principle of sound public finance as well as the fairness of the tax system are the ultimate goals underlying this Action.

The coordination of Action 4 with other Actions is expressly referred to: transfer pricing (related party financial transactions), hybrids (Action 2) and CFC rules (Action 3). In our view, the connections are quite clear, especially in the case of transfer pricing and CFC; the question is why not with Action 5, as long as preferential tax regimes may also affect the deductibility of interest. ${ }^{5}$ Apart from that, it should be clear the meaning and scope of 'coordination' because in this respect, there are at least two different aspects: First, the possibility of a kind of 'multiuse' measure; for instance, a concrete measure could serve to prevent aggressive tax planning both counteracting excessive interest deduction and the use of a hybrid instrument. Second, coordination also means compatibility and consistency with other measures; for instance, the so-called secondary adjustments as a result of transfer pricing rules (we will deal with this point later).

About the scope of Action 4, Brauner thinks that 'This Action shows more promise than Action 2 and a higher likelihood of collaborative solution'. 6 We agree with this view in the sense that as we will see later, limitations on the deductibility of interest is not a new question and depends mainly on domestic measures but, precisely for this reason, collaboration is unclear except in a supranational scenario such as, for instance, in the European Union, the proposed amendment to the ParentSubsidiary Directive. ${ }^{7}$

Calderón and Martín are very critical because of the lack of clear concepts ('excessive interest'), objectives (antiabuse/debt-equity) and connection with hybrids and arm's length. ${ }^{8}$ In our view, it is quite evident that in BEPS there is a lack of a solid conceptual background and sound and well defined principles (for instance: which are those 'new International Tax Standards' apart from avoiding double non-taxation as the new and explicit objectives of the Tax Treaties? $\left.{ }^{9}\right)$ but, to some extent it is useless and unnecessary to look for clear concepts in every word of an Action Plan as if it were a provision already enacted.

For the time being, the OECD has delivered reports on several Actions (the 2014 Deliverables), ${ }^{10}$ but Action 4 will be included in the next package to be delivered before September 2015.

Taking into account that the limitations on the deductibility of interest is not a new question, we will next deal with its justification and the two different kind of measures that have been or can be implemented in this respect.

\section{Notes}

In this respect, J. Hay considers that 'legislation could be categorized as either covering inbound and outbound cases uniformly by way of a general interest deduction disallowance for related-party debt and third-party debt or differentiated between inbound and outbound instruments, for example thin capitalization legislation in respect of related-party debt combined with restrictions for the deduction of interest financing tax-exempted dividends'. In 'Base Erosion and Profit Shifting and Interest Expenditure' Bulletin for International Taxation vol. 68, issues 6/7, 2014. IBFD.

See J. Hay, 'Base erosion ...'

Y. Brauner, 'BEPS: An Interim Evaluation' in World Tax Journal vol. 6, issue 1, 2014. IBFD.

Council Directive 2014/86/EU of 8 Jul. 2014 amending Directive 2011/96/EU on the common system of taxation applicable in the case of parent companies and subsidiaries of different Member States.

8 J.M. Calderón Carrero \& Adolfo Martín Jiménez, 'El Plan de Acción de la OCDE para eliminar la erosión de bases imponibles y el traslado de beneficios a otras jurisdicciones (“BEPS”): ¿el final, el principio del final o el final del principio?' in Quincena Fiscal, I-II, 2014. Thomson-Aranzadi.

See footnote 3 .

10 Action 1 (Digital Economy), Action 2 (Hybrids), Action 5 (Harmful Tax Practices), Action 6 (Treaty Abuse), Action 8 (Transfer Pricing, intangibles), Action 13 (Transfer Pricing, documentation) and Action 15 (Multilateral Instrument). See: OECD/G20 Base Erosion and Profit Shifting Project, Explanatory Statement (2014 Deliverables). 


\section{Limitations ON THE DEDUCTION OF INTER- EST}

\section{I Grounds for Justification}

Restrictions on the deduction of interest are increasing due to a change of tax policy in several tax jurisdictions which have enacted specific provisions in this respect. Apart from the recent concern on base erosion and profit shifting, several justifications, such as neutrality (debt/ equity), anti-abuse and sound public finance, can back this type of provisions.

The new provisions resulting from implementations of Action 4, similarly to the current provisions, could either combine all these justifications or be more focused in one of them (i.e., avoid double non-taxation). It will depend on the scope and content of the relevant provision, that will have to be interpreted according to its motivation; the connection with common justification with other Actions (i.e., Action 2 on Hybrids) will also have to be taken into account.

For the time being, most tax jurisdictions have tried to solve the problem of how limiting the benefits of debt characterization, by enacting and implementing two type of solutions that, through two different ways, look for the same result: the no deduction of interests.

The first way is what we would call an indirect solution, mainly based on the classification of the interest as a dividend and in this group, the thin cap rule, as well as secondary adjustments in transfer pricing, are the most extended and significant measures, but normally applicable to related entities. In most cases, they can be clearly identified as anti-avoidance provisions that try to fight aggressive tax planning schemes based on the benefit of debt characterization when financing entities within the same group.

The second way is a direct solution, by means of provisions that keeping the classification of interests as such, simply deny or restrict its deduction. These provisions may have a limited scope, when only applicable to related entities and/or with an anti-avoidance purpose, but also a more general scope, if applicable to any kind of entities whether related or not and irrespective any abuse purpose of the taxpayer entity.

The justification for this direct solution is a very simple but at the same time, in our view, a right statement according to which 'Interest is a deductible expense and, as such can be subject to restrictions and limitations as all business expenses can be' (Brown). ${ }^{11}$
It is, in principle, evident that not every business expense or cost is deductible for tax purpose, because the tax base is not necessarily identical to the net result of the profit and loss account and this can be said irrespective the system chosen by the tax legislator. Even in the cases of Corporate Tax legislations that, in principle, refer to that account for the calculation of the tax base, its provisions will regulate adjustments to the initial amount for some expenses (such as gifts, penalties or certain provisions) which may be considered non-deductible even if they represent and actual and effective cost.

In general, this has not been the case for the interest which, traditionally, has always been considered a deductible expense (this is precisely the problem, when we compare this situation to the one of the dividend). But however, we can find examples of non-deductible interests in some specific cases that have nothing to do with the problem of debt-equity. We are referring to tax legislations that, even having implemented a very similar tax treatment for subsidiaries and permanent establishments (PE) (including the calculation of the tax base), still retain some differences and one specially relevant is that the interests paid by the PE to the head company are not deductible (while the interests paid by the subsidiary to the parent company are deductible). ${ }^{12}$

As already mentioned, a first ground for justification is neutrality. Debt vs. equity which, at the income level, means interest vs. dividend has always been a relevant issue and a major concern in the field of taxation. ${ }^{13}$ To some extent, this could be considered a never ending story and a frequent matter of conflict between the Tax Administration and the taxpayers (in most cases, companies integrated in multinational groups).

Precisely because this is a global and everlasting problem, several and different solutions have been proposed. ${ }^{14}$ Most of them remain at the theoretical level or have been presented by Governments and International organizations as documents on tax policy proposals. Just to mention some of these, we can refer to: the Comprehensive Business Tax (CBIT) which would imply denial or restriction both on interests and dividends (US Treasury 1992); the deductibility of interest based on the relationship between risk and return (Polito, 1998); the Business Enterprise Income Tax (BEIT) which proposes an allowance for cost of capital, denying the deduction of interests and dividends at the entity level, not taxing them at the recipient level (Kleinbard, 2007); unlimited deduction for interests and dividends, taxing the retained earnings at the entity level (Warren 1981, Avi-Yonah

\section{Notes}

'The debt-equity conundrum' General Report, supra n. 1, at 40

This is the case in Spanish Non-Residents Income Tax Act (R.D.L. 5/2004, Art. 18.1.a).

That was one of the main subjects in the IFA Congress 2012 in Boston: 'The debt-equity conundrum' (General Report by P. Brown) Cahiers de Droit Fiscal International, volume 97 b, Sdu The Netherlands 2012.

14 See: Peter H. Blessing, 'The debt-equity conundrum. A prequel' on Bulletin for International Taxation, April/May 2012 , pages 198-212. 
2010); the Allowance for Corporate Capital (ACC) based on a deduction for the risk-free return on capital whether from debt or equity, but thus denying the deduction both of interests and dividends (IMF 2011). Also encouraged by the IMF, the Allowance for Corporate Equity (ACE) is a different proposal, which in part consists in the current situation, based on the deduction of interests but not of dividends, allowing a deduction on the amount of the corporate equity; this system has been enacted in a few tax jurisdictions.

In recent years, some countries such as Belgium and Italy have enacted provisions based on the ACE system. ${ }^{15}$

Just to summarize: neutrality when financing an enterprise requires a similar treatment of debt and equity which, at the income level, means same treatment of interest and dividend; this can be achieved either declaring both deductible or non-deductible. The two ways for neutrality have been proposed in the different alternatives above mentioned but in this respect, we may conclude that the principle of neutrality can back a provision limiting the deductions of interests, but also that neutrality can be achieved not only and exclusively by means of that limitation.

The second ground for justification is anti-abuse legislation trying to counteract the debt bias. In this respect, it can be said that the indirect solution based on the reclassification of interest as dividend has not worked properly; to some extent, we are facing a relative failure of the thin capitalization provisions. At the EU level, this is in part due to the European Union Court of Justice doctrine, in a first step, by its decision in the LankhorstHohorst case; in a second step, by the most precise doctrine set out in the Thin Cap case.

Also in line with the prevention of abuse, we must refer that another justification directly linked to the new international tax standard proposed by BEPS and precisely expressed in Action 4 is the need to avoid double nontaxation.

In the following points we will deal with the two last questions, based on the experiences both with limitations based on classification and to financial expenses related to exempted income.

Last but not least, a third ground for justification is linked to the principles of sound public finance and fairness of the tax system (i.e., 'fair share' by MNEs), which may legitimate provisions of this kind, which tend to prevent base erosion in Corporate Tax. The challenge in this case is to find a fair balance between the public interest (revenue) and a fair tax burden on the taxpayer, according to the principles of ability to pay and equality.

\subsection{Limitations Based on Classification}

The indirect solution of the debt bias can be either the result of classification in a particular case or of specific anti-abuse legislation, such as the thin capitalization provisions.

Classification on a case by case basis is not effective as a general solution, because the result will depend on a final Court decision. We refer as an example, the US Tax Court decision given by Judge D. Kroupa in the Scottish Power case in 19 June 2012; the IRS had challenged 932 million dollar in interest deduction, considering that the related debt had to be treated as equity, but the Court ruled that: '...there are in this case pointing to both debt and equity ... nevertheless in view of the record as a whole, we find that the advance was more akin to debt than equity' and therefore held that 'the payments of interest made with the respect to the loan notes are deductible for each year at issue'.

In most countries, specific provisions focused on the concept of thin capitalization have been enacted, the result being the no deduction of the excessive interest. In our view, whether this interest is expressly reclassified as dividend or not is irrelevant, because the result (no deduction) is the same and it can be considered that classification is the underlying idea, in the sense that the excessive debt is considered as 'disguised' equity. As already mentioned, we are now facing a relative failure of this type of provisions, especially in the European Union, due to the ECJ doctrine in this respect. In view of future provisions implementing BEPS Action 4, some lessons can be learnt from this experience.

It is well known that the ECJ decision on the LankhorstHohorst case (C-324/00, 12 December 2002), declared the German thin cap rule contrary to the freedom of establishment because of the 'difference in treatment between resident subsidiary companies according to the seat of the parent company', rejecting three possible justifications: First, the protection of the tax revenue, because according to the Court's doctrine 'does not constitute an overriding reason in the public interest which may justify a measure which is in principle contrary to a fundamental freedom'. Second, the risk of abuse because that provision 'does not have the specific purpose

\section{Notes}

15 See. EU Commission, 'Adressing the Debt Bias. A Comparison between the Belgian and the Italian ACE Systems'. Working Paper n. 44, 2014. According to the Belgian system (2006), a corporation is granted a deduction against the Corporate Income Tax base equal to the product between the (adjusted) equity, the ACE base, and a given notional rate, the ACE rate. This regime is applicable both to resident and non-resident companies with a PE in Belgium and antiabuse provisions apply, In Italy (2011), the ACE is a deduction against the Corporate Income Tax base meant to approximate the cost of equity, calculated by applying a notional interest rate to a net equity base, the ACE base, defined on the net positive variation of equity as for the end of 2010. The regime applies to resident and non-resident companies with a PE in Italy. 
of preventing wholly artificial arrangements designed to circumvent the German tax legislation, from attracting a tax benefit, but applies generally'. Third, the coherence of the tax system because the Court considered that there was not a direct link between the deductibility in the subsidiary company and the taxation of the parent company.

The decision on the Lankhorst-Hohorst case led to different reactions by the Member States, from (the most common) consisting in applying their thin cap provision also in purely domestic situations, to the opposite (i.e., Spain since 2004), consisting in declaring that the thin cap rule does not apply within the European Union. According to most scholars (and this is our view too) that reaction of the Spanish legislator was disproportionate and not very logical, apart from arising other problems, such as the possible use of conduit companies located in Spain, thus circumventing the thin cap rules retained in other Member States, or the discrimination of third countries. Precisely in this respect, the Tribunal Supremo (Spanish High Supreme Court) in its decision of 17 March 2011 on the Hero case (a Swiss company), ${ }^{16}$ based on Article 24.1 (non-discrimination) of the Tax Treaty (DTC) between Spain and Switzerland, stated that the former thin cap provision ${ }^{17}$ could not apply in this case, because companies resident in Switzerland have the right to the same tax treatment as companies resident in Spain.

The decision on the Thin Cap Litigation Group case (C524/04, 13 March 2007), set out a more precise doctrine with two relevant elements: First, connecting the compatibility of the thin cap provisions with the freedom of establishment with the Court's doctrine on abuse of law. Second, determining the limits of the classification according to the principle of proportionality which in this case, means to put these limits within the framework of the arms' length principle.

Therefore, a thin cap provision as long as it applies to the interest of a loan directly or indirectly granted by a company resident in another Member State is in principle, an obstacle to the freedom of establishment prohibited by the Treaty, unless: first, the provision contains objective elements identifying purely artificial arrangements and the possibility for the taxpayer to justify commercial justification and second, if abuse is proved, the classification of the interest as a dividend will be only in so far it exceeds the amount due according to arms' length principle. This doctrine was further invoked in the Court's decision on the NV Lammers $\mathcal{E}$ Van Cleeff case (C-105/07, 17 January 2008). ${ }^{18}$

In Spain, the arms' length test as a limitation to the effects of the thin cap provision was also followed by the Tribunal Supremo in its decision on the Hero case above mentioned. The Court argued in base of Article 9 of the OECD Model Convention, stating that the compatibility of the national thin cap provision with Article 9 requires the proof by the Tax Administration that the benefits obtained have been higher than those that would have been obtained according to the arms' length principle. In the Netherlands, the Hoge Raad in its decision of 21 September 2011 held that the Dutch thin cap provision which denied the deductibility of interest related to excessive debt (3 to 1 debt/equity ratio) was consistent with Article 9 of the relevant Tax Treaty.

The consistency of the provisions limiting the deductibility of interest with the arm's length principle is in our view, a major issue, especially when dealing with Article 9 of the Tax Treaty as we will see later on, but also in general, in the cases of domestic transfer pricing provisions which apply the so-called secondary adjustment, that is to say, classification as dividend of the excessive interest according to that principle. ${ }^{19}$ This type of adjustment shows that transfer pricing provisions also have an anti-avoidance objective, as far as the excess of interest (according to arm's length) is considered as a hidden dividend.

To summarize: from a EU Tax Law perspective, thin capitalization as a targeted anti-avoidance rule can be, in principle valid and compatible with the Treaty but its application must be proportionate according to an arms' length test

\subsection{Financial Expenses Related to Exempted Income}

Double non-taxation has been targeted by BEPS and counteracting this effect is one of the major issues addressed in the Action Plan. As we have already mentioned, the rule expressly recommended by Action 4 is to deny the deduction of interest related to exempted income. Moreover, recent EU initiatives have moved in the same direction.

But just ten years ago, this was not the case. In EU Tax Law, the Parent / Subsidiary Directive was aimed to

\section{Notes}

Tribunal Supremo (Sala de lo Contencioso) 1825/2011, 17 Mar. 2011

Article 20 Corporate Tax Act (abrogated in 2012).

On 6 Jun. 2012, the South Central Administrative Court (Portugal) has requested from the ECJ a preliminary ruling regarding the non-deductibility of interest on excessive debt towards an entity of a non-member country with which special relations are maintained.

19 Such as, for instance, Art. 16.8 of the Spanish Corporate Income Tax Act, according to which in cases of difference in favor of the shareholder, this amount, in proportion to the share, will be considered as participation in the profits of the company. 
correct double taxation, both economic (by either imputation or exemption system on dividends in the State residence of the parent company) and legal (by exemption on dividends in the State of source) and the same objective had the Directive on Interest and Royalties between associated companies (elimination of legal double taxation by exemption of interest in the State of source). But none of these two Directives prevented from double nontaxation; this seemed not to be an issue at that time and the Bosal case illustrates that situation.

The ECJ decision on the Bosal case (C-168/01, 18 September 2003) dealt with a Dutch provision that did not allow the deduction of the so-called participation costs of a holding, unless they were related to profits taxable in The Netherlands. The problem in this case was connected with the Parent/Subsidiary Directive (90/435), because as far as the dividends from the subsidiaries in another Member State were not taxed in the State of the parent company, the interest paid by this company as participation cost in its subsidiaries, did not meet the requirement for being deductible according to that provision.

It must be taken into account that the Directive in its Article 4, after granting the exemption or a tax credit in the State of residence of the parent company on the profits distributed by its subsidiaries resident in other Member States (paragraph 1), declared that 'each Member State shall retain the option of providing that any charges relating to the holding and any losses resulting from the distribution of the profits of the subsidiary may not be deducted from the taxable profits of the parent company' (paragraph 2). Based on this provision, The Netherlands and UK Governments, as well as the Commission, argued that 'it is lawful for Member States to provide that costs in relation to holdings are not in any way deductible from the taxable profits of the parent company'.

The Court accepted this argument and thus declared the limitation in principle, compatible with the Directive, but stating at the same time that the possibility referred in Article 4.2 'may be exercised only in compliance with the fundamental provisions of the Treaty' and therefore, a provision like the one in the case at hand, which limits the deductibility of costs incurred by the parent company when the related profits are distributed by the subsidiaries in other Member States 'constitutes a hindrance to the establishment of subsidiaries in other Member States' and moreover, goes against the objective of the Directive, which is to eliminate the tax disadvantages in the relations between parent companies and subsidiaries within the EU.

Also in this case, the Court rejected the justifications based on the coherence of the tax system (no direct link because parent and subsidiaries are different legal persons and neither between the cost of the parent and the potential taxable profits of the subsidiaries), territoriality (no such an exception in the Directive), and avoiding the erosion of the tax base (for this is a justification similar to the risk of diminution in tax revenue, that has been traditionally rejected by the Court as a matter of overriding general interest).

The Court finally declared contrary to the freedom of establishment:

a national provision which, when determining the tax on the profits of a parent company established in one Member State, makes the deductibility of costs in connection with that company's holding in the capital of the subsidiary established in another Member State subject to the conditions that such costs State where the parent company is established.

It is interesting to note that the Dutch provision fell under Treaty freedoms and not as a result of the interpretation of the Directive and this may be the reason why some authors think that the Bosal doctrine would be an inconvenient in order to implement provisions of that kind within the EU ${ }^{20}$ but, in our view, things may change if a specific provision aiming to avoid double nontaxation, were included in the Directive and thus implemented by national legislations in all Member States.

Nevertheless, it must be noted that the Parent Subsidiary Directive applies to cross-border situation, when the parent company and its subsidiary are located in different Member States. In the Bosal case, although the exemption on the dividends from EU subsidiaries was an effect of that Directive, the problem arose in a domestic situation referred to the Corporate Tax base of the Dutch parent company: the financial expenses were not deductible because the related income (dividends from EU subsidiaries) was not included in that base.

In other words: the risk of double non-taxation in cases of interest deductible related to exempted income, can be either arisen in a purely domestic or in a cross-border situation. Both cases have to be solved by changes in the domestic legislation, but in the cross-border cases, especially within the EU, the national provisions could be uniformly adopted by way of implementation of a Directive.

Recently, the Council Directive amending Directive 2011/96 /EU on the common system of taxation applicable in the case of parent companies and subsidiaries of different Member States ${ }^{21}$ includes as new wording in Article 4.1.a): 'refrain from taxing such profits to the

\section{Notes}

20 See J. Hay, 'Base erosion ....'

21 Council Directive 2014/86/EU of 8 Jul. 2014. 
extent that such profits are not deductible by the subsidiary of the parent company'. ${ }^{22}$ This provision tries to avoid economic double non-taxation focusing in the tax treatment of the dividends in the State of residence of the parent company; therefore, it is not a provision aiming to deny the deduction of interest. Obviously, one may think that dividends are not deductible as a general rule, and if this were the case, it would be either a result of specific provisions in the State of the subsidiary or of hidden dividends disguised as interest; in other words, we are facing here a question related to hybrids, although the proposal focus on one-side direction. ${ }^{23}$

The situation is far from being exceptional o merely theoretical. We can refer as an example the one of the socalled juros brasileños regarding the dividends paid by Brasilian subsidiaries to their parent companies and the related Court decisions in Germany (Federal Court 6 June 2012) and Spain (Audiencia Nacional 27 February 2014).

According to the Brasilian Federal Act (1996, Article 9), the juros qualify as equity and the subsidiary is a shareholder of the parent company, but the related profits distributed are called 'interests' and are deductible in order to calculate the tax base of the subsidiary. Article 21 of the Spanish CIT grants a participation exemption regime for foreign dividends ( $5 \%$ threshold).

In this case, the Spanish Tax Administration considered that the 'dividends' obtained by the Spanish parent company should be reclassified as interest income and thus, not being dividends, Article 21 CTA did not apply. The Court, focused on the relevant provisions of the relevant Tax Treaty between Brasil and Spain, specially the concept of dividend (Article 10) and interest (Article 11) which, according to the Court shall be interpreted following the rule in Article 3.2, which meant in this case, according to the Brasilian legislation. Following this reasoning, the Court considered that the payments corresponding to the juros qualify as dividends and therefore, the exemption granted by Article 21 CTA applied in this case. The Audiencia Nacional expressly invoked the former decision held by the German Federal Court on the same case which considered that the juros qualified as dividends according to the German legislation.

As far as our topic is concerned, it is important to remind that Action 4 expressly refers to coordination with Action 2 on hybrids and one proposal recommended in this Action is to develop '(iii) domestic law provisions that deny a deduction for a payment that is not includible in income by the recipient (and is not subject to taxation under controlled foreign company CFC or similar rules)' ${ }^{24}$ The Action also refers the reverse proposal (similar to the amended Article 4.1.a) of the Parent / Subsidiary Directive): 'domestic law provisions that prevent exemption or non-recognition for payments that are deductible by the payer'. The recent document delivered on Action 2, contains specific proposals in both directions, either denying the deduction of payments in the payer jurisdiction and/or denying exemption (i.e., dividends) for deductible payments. ${ }^{25}$

It seems that these type of provisions address crossborder situations, the typical case being: payment deductible in the State of residence of the payer and the related income exempted in the State of residence of the recipient. But it must be noted that double non-taxation could also arise in a purely domestic situation, such as financial expenses related to exempted income in the same State; that was the case in Bosal where although the income came from foreign dividends, both this income and the related financial expenses were included in the tax base of the Dutch Corporate Tax. ${ }^{26}$ In our view, all situations of double non-taxation should be treated equally, because they are comparable; otherwise, there would be a problem of discrimination, especially within the EU and also in this case, a risk of restriction on Treaty freedoms.

Nevertheless, we must bear in mind that the ambitious objective of avoiding double non-taxation, although formally legitimated by the need to counteract aggressive tax planning, is not always a result of that planning at all. More especially, in the case of interest deductible (in State A) related to exempted income (in State B), double nontaxation may be the result (not even intended by the taxpayer) of a mismatch between the legislation of State A and State B.

From this perspective, either of the two solutions proposed may be debatable, moreover if the taxpayers in A and $B$ are not related parties. In the first case, because the deduction of interest in State A will not be deductible (more tax burden for taxpayer in A) because of tax policy measures (exempted income) adopted in State B (benefit for taxpayer in B). In the second case, because a tax policy measure adopted by State B (exemption) will not be applied because of a tax provision (deduction of interest) adopted by State A. Moreover, these solutions are also

\section{Notes}

A similar provision is implemented by Art. 21.1.b) of the new Spanish Corporate Tax Bill (published 6 Aug. 2014, Boletin Oficial de las Cortes Generales).

23 For a critical approach to this proposal, see: H. van der Hurk, Proposed Amended Parent-Subsidiary Directive Reveals the European Commission's Lack of Vision in Bulletin for International Taxation, September 2014. IBFD.

\footnotetext{
A provision of this kind is implemented in the Spanish Corporate Tax Bill (Art. 15 j).
}

See: OECD/G20 Base Erosion and Profit Shifting Project 'Neutralising the Effects of Hybrid Mismatch Arrangements' (Action 2:2014 Deliverable), Chs 2, 3 and 4.

About a general limitation on the deduction of interest on related-party and third-party debt, J. Hey thinks that 'a targeted solution would only inhibit the deduction of interest related to tax-exempt or deferred foreign dividends, whereas interest related to domestic tax-exempt dividend would still be deductible, thereby preventing double taxation', although the author notes that this could be blocked by ECJ in Bosal. See 'Base erosion ...'. 
debatable from the perspective of the tax jurisdictions involved, because the effective application of the tax policy measures adopted by one State will be conditioned by the tax treatment of the related (income/expense) in the other State. ${ }^{27}$

\section{The RELEVANT PROVISIONS}

\section{I Some Comparative Examples}

As we have already mentioned, some tax jurisdictions have enacted provisions either denying or limiting the deduction of interest. ${ }^{28}$ The content of these provisions may show differences but their common feature is the nondeductibility of interest and other financial expenses. In this respect, the scope may consist either in a limitation of the amount deductible (the so-called ceiling rule) or in the denial of deduction, the reference can consist in the profits (i.e., EBITDA) or in the equity capital and the effects the no deduction (direct solution) or the reclassification of the interest (indirect solution). Although not exclusive, these are the main features of the current provisions enacted in different tax jurisdictions.

Just to summarize some relevant examples, we can refer to the German provision which only accepted the deductibility of the net interest, limited to the $30 \%$ of the EBITDA. The provision is applicable to all kind of interest, irrespective whether the parties are related and not conditioned by any arms' length requirement. The excess of no deductible interest can be carried forward for five years. The rule admits some exceptions, such as a net amount below EUR 3 million or in the case of groups, an equity ratio higher than the relevant group's equity ratio. We want to point out the remark made by the German reporter: 'The rule ultimately causes double taxation, as interest earned is taxable at creditor level, while the interest expense may not be fully deductible at borrower level'. ${ }^{29}$

A similar provision was enacted in Italy in 2008. The thin cap rule was abrogated and according to the new one (not applicable to financial entities and individuals) if the interest expense exceeds the amount of the interest income, its deductibility is limited to $30 \%$ of the benefit with a carry forward for the no deductible excess. Apart from this, it must be taken into account that in the IRAP (a regional business tax, similar to the German Gewerbsteuer) the interest is not deductible.

In the United States, according to the relevant provision in the IRC (163 j), taxpayers with a too high debt-equity ratio or an excessive interest expense, are not allowed to deduct some or all of their related party interest in the current year if the related party pays no tax or a lower tax on the interest income. As the US reporter remarks, the provision 'does not confront the status of the instrument directly, and it does not seek to challenge the taxpayer's classification of the instrument as debt. Instead, the provision accepts the instrument as debt, but then takes away debt's most attractive tax feature, the issuer's ability to deduct interest'. ${ }^{30}$ We retain now this remark which in our view, expresses one of the reasons why some legislations have moved from indirect solutions (such as thin cap) to a direct solution (no deduction of interest): a more pragmatic approach thus avoiding the legal conflicts related to classification.

The French provision (May 2012) enacted in the CGI (Article 209.IX) ${ }^{31}$ had a different content. In this case, the no deduction of the interest is implemented by recapture (réintégration) of the financial expenses related to the acquisition of shares if the amount exceeds EUR 1 million and the purchasing company cannot by any means demonstrate that the shares are held by this company or indirectly by a company resident in France and also, that the control over the participated company remains in the hands of a company resident in France. The recapture will apply in the fiscal year related to that demonstration with a carry forward of eight years. The pending recapture will be applied for the subsequent companies in cases of merger or division.

It seems obvious that the aim of this provision is to avoid the use of French companies as mere conduit companies and therefore, this recapture mechanism may be considered an anti-avoidance rule. But the wording and effects of the provision, definitely put in a better position the companies owned and/or controlled by French. In our view, it seems difficult to accept such a provision from a EU Law perspective according to the relevant ECJ doctrine; as it has already been remarked, the recapture provision 'tends to demonstrate that the objective pursued by the legislator is not really the symmetry principle but rather to make it less attractive for a group of companies to outsource and relocate functions outside France. It goes

\section{Notes}

27 J. Hey has observed that a general non-deductibility and/or reclassification of related-party debt 'would result in a fundamental change in the revenue distribution between source and revenue countries'. See 'Base erosion ...'.

28 Some of these provisions were described in 'The debt-equity conundrum' supra n. 1. See in this respect National Report Germany (by Fischer), National Report Italy (by Mamelli) and National Report United States (by Ring).

Fischer, National Report Germany, page 319.

Ring, National Report United States, page 784

31 Code Général des Impôts modified by Décret $n^{\circ}$ 2012-653. 
without saying that such a protectionist objective, which is directly in conflict with the main purpose of the internal market, will not elicit the Court's indulgence'. ${ }^{32}$

Spain is another tax jurisdiction that moved from indirect to direct solutions. The Royal Decree 12/2012 of $30 \mathrm{March}^{33}$ abrogated the former thin cap rule (Article 20 Corporate Tax Act) and enacted two different provisions (Article 14.1.h) and Article 20) in order to deny and restrict the deduction of interests and declaring both provisions applicable since 1 January 2012. These provisions imply important modifications in the Corporate Tax Act, more precisely in the rules for the calculation of the tax base. It must be noted that the aim, scope and effects of these two provisions are different, because Article 14.1.h) can be considered a special anti-avoidance rule (SAAR) trying to counteract a concrete scheme of tax abuse denying the deductibility of the related-parties interest (intragroup debt) unless the entities prove a valid economic purpose of the transaction; Article 20, very similar to the German provision already mentioned, has a more general scope irrespective any situation of tax abuse and thus, although implying a limitation, its consequences are less severe for the taxpayer, because the limitation consists in a 'ceiling rule' of $30 \%$ of the so-called net operational benefit (similar to EBITDA) with a carry forward (18 years) for the amount not deducted.

In our view, some of these provisions can be considered as the 'rules' mentioned in BEPS Action 4 and from this perspective, further implementation might not be necessary. However, it must be reminded that this Action focuses on anti-abuse and more precisely on double nontaxation (deduction of interest related to exempted income), which means that most of the current provisions may not cover all the goals of Action 4 but also that this Action does not necessary legitimate all those provisions. For instance, regarding the Spanish provisions, we think that Action 4 can back Article 14.1.h) which is an antiabuse rule counteracting artificial intra-group financing, but it is unclear that the general 'ceiling rule' in Article 20 could be legitimated by that Action.

Article 14.1.h) of the Spanish CTA declares nondeductible the financial expenses accrued in the fiscal year related to debts with entities of the group (according to Article 42 of the Code of Commerce), irrespective the residence and the obligation of consolidate their accounts, if the loan is for the acquisition of shares from other entities of the group or from any other entities, or for investing equity capital in other entities of the group, unless the taxpayer demonstrates that such transactions have a valid economic purpose.

To some extent, it can be said that this was a tailormade provision in order to counteract a certain type of tax planning scheme which had been identified by the Tax Administration. The most common and significant example was the situation of a multinational group including operating companies in Spain with business activity and generating profits (the so-called Spanish subgroup). This being the starting point, a tax planning scheme was developed through the following steps: First, the group incorporated in Spain a holding company, which benefited from the ETVE tax regime. ${ }^{34}$ Second, the holding incurred in debt with other companies of the group (in most cases, the lender companies were resident in lower tax jurisdictions or enjoying from tax benefits 35 ); the loan was for the acquisitions of shares from other companies of the group (shares held by other holdings of the group resident in other countries) or either for investing in equity capital in other companies of the group; as a result of the big amount of the interests generated by these loans, the Spanish holding had a significant loss. Third, the Spanish subgroup opted for the consolidation tax regime, where the losses of the holding were offset with the profits of the operating companies. The final result was obviously, an important erosion of the tax base of the Spanish subgroup and therefore, a significant loss of revenue for the Spanish Treasury.

Before the current provision in Article 14.1.h) CTA was enacted, the Tax Administration challenged this scheme by applying the GAAR in Article 15 of the Ley General Tributaria (General Tax Act, GTA). According to this provision, the Tax Inspector can disregard transactions clearly artificial or inadequate its main purpose being to get a tax advantage. In the case at hand, the consequence would be to deny the deduction of interests by the holding company and in the end, the taxation of the profits generated by the operating companies. The TEAC (Tribunal Económico-Administrativo Central, an administrative Tax Court), backed the position of the Tax Administration in some of its decisions ${ }^{36}$ and set out the criteria that must be met for rejecting this type of scheme, such as: the acquisitions do not mean any actual investment neither any value added for the group; the Spanish holding does not perform any functions of direction or administration in the participated companies;

\section{Notes}

E. Robert, 'New Limitations on the Deduction of Financial Expenses Related to Acquisitions' in European Taxation, May 2012, page 260.

Real Decreto-Ley 12/2012, de 30 de marzo (Medidas tributarias dirigidas a la reducción del déficit público). B.O.E.31 de marzo.

34 'Entidades de tenencia de valores extranjeros'. (Entities holding securities in foreign companies). The benefits of this special tax regime consist basically in: the profits obtained by the holding are exempted in the CT and the dividends distributed by the holding company to its non-residents shareholders are neither taxed in the Non-Resident Tax (NRT) (the resident shareholders also benefit from an exemption on these dividends in the CT).

Such as, for instance, the so-called Coordination Centres in Belgium, where the income interests generated by these companies were taxed at a low rate or not taxed at all.

TEAC, resoluciones (decisions): 17 May 2007 and 25 Jun. 2009. 
the internal documents of the group show that the negative results of the holding are only relevant within the tax consolidation regime, but vis-à-vis third parties, the external image of the Spanish subgroup, only related to the benefits of the operating companies, is positive. However, in another case when the Tax Administration failed to prove the tax abuse because the acquisitions were made by a Spanish operating company with the intention to create an 'Iberian subgroup' (together with Portuguese companies) in order to enlarge their business activity, although the lender company was a "coordination centre' of the group resident in a third country, the Court accepted that there was a valid business purpose and ruled in favour of the taxpayer (the Spanish borrower company), thus accepting the deduction of the interests. ${ }^{37}$

In our opinion, Article 14.1.h) of the Spanish CTA is the type of provision that fits within the objectives of BEPS Action 4, but the correct implementation of this Action will also require another type of provision, related to both related and third party debt in order to deny the deduction of interest related to exempted (and/ or deferred) income; the future implementation of the amended Parent/Subsidiary Directive could be a first step in this direction.

We want to remark that the denial of deduction is a severe consequence for the taxpayer, legitimated by the need to prevent and correct the tax abuse scheme, but its indirect consequence, in the case when the interest income obtained by the lender company is taxed, will be a double economic taxation of the interest. In our opinion, this can be a major problem arising from the provisions which deny or restrict the deduction of interests that, normally, do not contain any reference to bilateral adjustment, probably because in the most usual tax planning scheme above described, the interest income will not be taxed in the State of residence of the lender company, but this reason does not avoid the problem, if the current provision applies whether the interest income obtained by the lender is taxed or not. Moreover, in the case of a non-resident lender, it must be taken into account that this income may also be taxed in the State of source (legal double taxation). In fact, the problem can arise from taxation of the interest income either in the State of residence, in the State of source or in both.

\subsection{Legal Principles and Taxpayer's Position}

The provisions such as the above mentioned, deserve some comments from the perspective of the legal principles involved.

The OECD has expressed that 'While there is a clear commitment to the fight against BEPS practices, the changes that will be proposed should not create legal uncertainty, nor increase the risk of double taxation'. ${ }^{38}$

These are good intentions but, for the time being, the current provisions dealing with limitations on the deduction of interests may arise some questions in this respect.

First of all, the provisions should be analysed from the perspective of the principle of legal certainty, which has always been a major concern, especially when dealing with anti-abuse rules. The question is: do direct solutions consisting in the denial or limitation on the deduction on interest provide legal certainty in order to avoid legal conflicts in the future? This issue will be analysed later on, when dealing with the taxpayer's position.

Another principle to be considered is neutrality. In this respect, it seems obvious that the provisions which deny or limit the deduction of interest, approach its tax treatment to dividends. However, as far as neutrality is concerned, some remarks can be pointed out. First of all, this type of provisions can be backed by that principle, but we have to bear in mind that neutrality in the taxation of interest and dividend can also be reached by other means. Moreover, neutrality cannot be properly achieved because of the risk of double taxation of interest, unless this double taxation is not corrected; in fact, in the most common case, when the tax legislation provides complete relief from economic double taxation of dividends, there will be no neutral balance in disadvantage for the tax treatment of interests. The risk of economic double taxation should also be considered in the provisions related to hybrid instruments. 39

The problem of double taxation of interest, was raised in the Scheuten Solar Technology case (C-397/09), decided by the ECJ on 21 July 2011. This case was about the conflict between a German provision and the Directive 49/2003 on a 'Common system of taxation applicable to interest and royalty payments made between associated companies of different Member States'.

\section{Notes}

TEAC, decision 1 Jun. 2010

OECD, Explanatory Statement (2014 Deliverables), page 9

39 In this respect, it has been pointed out that 'It is not very clear how genuine transactions would escape unharmed, especially in cases in which an advantage is offset twice. Preferably, recommendation would cover the risk of disadvantages for taxpayers to the same extent as the risk of double non-taxation' See: O. Popa, 'Hybrid Entity Payments-Extinct Species after the BEPS Action Plan?' in European Taxation, September 2014. IBFD. 
The German provision was the Gewerbesteuergesetz (Business Tax Act). When calculating the tax base, Article 8.1 provided to add back to the profit half of the payments for the debts which are connected economically with the foundation or acquisition of the operation (or part operation) or a share in the operation or with the expansion or improvement of the operation or serve the non-temporary increase of operating capital', which means, obviously, that $50 \%$ of the interest is not deductible.

Precisely for this reason, SST argued that this provision provoked double economic taxation on the interests and thus it was contrary to Article 1.1 of the Directive which granted an exemption of the interest payments in the State of source, the aim of the Directive being the elimination of double taxation. The Court however, declared that in the light of a right interpretation, Article 1.1 of this Directive aims to avoid legal double taxation and at the same time, its subjective scope is to exempt from tax the creditor, and not the debtor, so it cannot be extended beyond the exemption it lays down.

In our view, the reasoning of the Court when interpreting the Interest \& Royalty Directive was formally right, but the problem raised by this case dealing with the economic double taxation of interest, remains unsolved. The Parent/Subsidiary Directive tried to solve both legal and economic taxation of dividends and the only reason why the Interest \& Royalty Directive only solved the problem of legal double taxation is simply because as far as interests (and royalties) are normally deductible, there is no double economic taxation. Needless to say, this unsolved problem will become more and more relevant as long as provisions denying or limiting the deductibility of interests will spread their influence.

For the time being it is difficult to get a general conclusion about whether the provisions limiting the deductibility of interests enacted by different Member States are compatible with EU Law or not; this is a question to be solved on a case by case basis, but precisely for this reason, it can be said that there is not a priori, any 'red light' that prevents Member States from enacting this type of provisions in their tax legislation. In any case, EU legal constraints will have to be taken into account by Member States when adopting future provisions implementing BEPS Action 4.

The risk of double taxation is also connected with another relevant legal constraint which can substantially affect the taxpayer's position: the ability to pay principle. ${ }^{40}$

The provisions which deny or restrict the deduction of financial expenses have a direct effect on the final tax burden and therefore on the fairness of the tax system, so they have to be confronted with the ability to pay principle, especially in the tax jurisdictions where this principle is enshrined in the Constitution. In the case of an anti-abuse provision, this principle has to be balanced with the aim of preventing from tax abuse and also it could be considered that the principle cannot be invoked in the case of artificial transactions with no economic substance; however, economic double taxation if effective, can be considered a breach of that principle. In the case of a general provision, the approach can be different; for instance in the cases of a 'ceiling rule' allowing a carry forward compensation for the excess of interest not deducted, the limitation is not absolute and the risk of double taxation becomes actually a time mismatch; but also in this case, the ability to pay principle should be confronted and balanced with the principles and objectives that justify the provision.

Last but not least, as we have already seen, in the case of EU Member States, the provisions limiting the deductibility of interest, the principles of nondiscrimination and no restriction, as well as ECJ doctrine on these principles and on anti-abuse provisions, shall be taken into account.

Coming back to the principle of legal certainty, we will also refer some of the concerns about the taxpayer's position related to the application of the provisions limiting the deductibility of financial expenses.

The first concern is about the retrospective effect of these provisions on mid and long-term loan transactions. We will illustrate this with an example: in 2009, the parties agreed on a long-term loan, interest were deductible according to the CIT legislation in force at that time. In 2012, a new provision denying the interest deduction was enacted, coming into force in the fiscal year 2012.

In such a case, there is no retroactive effect, because the provision applies to the taxpayer's liability in the subsequent years. However, there is a retrospective effect on the long-term transaction and in these cases, the main question is: was the new provision reasonably foreseeable at the time when the transaction took place?

In this respect, we must bear in mind that the principle of legal certainty based on legitimate expectation has been considered a general EU Law principle by the ECJ. ${ }^{41}$ This principle has also been invoked by the Constitutional Court (Germany, Spain) in cases of retroactivity. Moreover, the jurisprudence of the European Court of Human Rights should be taken into account, especially its doctrine on the 'fair balance' between the protection of the property right

\section{Notes}

40 In this respect, J Hey states that 'Comparability with the ability to pay principle of taxation of net income involves that, on the one hand, interest expenditure should not be deducted twice, but on the other, that it cannot be disregarded and must be recognized somewhere. Countries seeking to prevent double non-taxation should, therefore, be equally aware of not causing double taxation". See "Base erosion ...'

41 (i.e., cases C-98/78, C-99/78, C-368/89, C-487/01, C-7/02, C-381/07 or C-396/08). 
and the legitimate tax legislation (Protocol 1, Article 1 of the Convention). According to this doctrine, one of the conditions of the 'quality' of the tax legislation required by the principle of legal certainty is that the law should be foreseeable. ${ }^{42}$ In our view, the retrospective effect of the provisions limiting the deductibility of interest should be confronted with that doctrine and also with the principle of proportionality. However, the situation of the future provisions that may be enacted as a result of implementing BEPS Action 4 will be very different from that perspective because, precisely for the previous knowledge of this Action, these provisions could be considered foreseeable.

Another concern on the taxpayer's position is about the burden of proof, especially in the case of anti-abuse provisions. These provisions may provide an exception if there is a valid economic purpose for the transaction but the taxpayer has to prove this purpose (i.e., Article 14.1.h) of the Spanish CIT). In our view, the rule on the burden of proof in this type of provision has to be balanced according to the principle of proportionality.

In this respect, we can refer the ECJ decision on the SIAT case (C-318/10, 5 July 2012). This case was about deduction of expenses related to exempted income in another Member State. According to the Belgian legislation (Code Général des Impôts 1992, Article 26), unusual or gratuitous advantages granted by an undertaking established in Belgium, those advantages shall be added to the profits if they are granted to a taxpayer (or PE) exempted or with a preferential tax regime in the State where it is established; the authenticity and the amount of those expenses must be proved related to genuine and proper transactions and not exceeding the normal limits.

The Court accepted the justification based on the need to combat tax evasion and avoidance, but considered that the provision can be applied without testing the existence of a wholly artificial arrangement, since it takes only into account the level of tax imposed on the service provider in the Member State where the provider is established; therefore, as it is, a rule that does not meet the requirements of the principle of legal certainty cannot be considered to be proportionate to the objectives pursued.

The taxpayer's position can also be affected by time limits related to statute of limitation and the audit procedure.

We will illustrate this with the following example: A long-term loan transaction was agreed on 2000. In 2007 the Tax Administration initiated an audit procedure on CIT for the fiscal years 2002-2005; in this procedure the deduction of interest was not challenged. In 2012, the Tax Administration initiated another audit procedure on CIT for the fiscal years 2007-2010 and this time the deduction was not accepted because, based on application of a GAAR, the loan was considered an artificial transaction.

Similar cases have been decided by the Spanish High Supreme Court. ${ }^{43}$ In this respect, the Court considered if the Tax Administration agreed to the transaction, without any change of the circumstances cannot, in subsequent years, consider that the transaction is abusive and thus denying the deduction of the related financial expenses. The Court expressly invoked the principle of legal certainty and legitimate expectation, as principles that apply in the relationship between the Tax Administration and the taxpayer and moreover, considered that an antiabuse provision cannot apply to transactions affected by the statute of limitation.

In our view, the future implementation of anti-abuse provisions limiting the deductibility of interest, should be aware of this concern. In this respect, we also think that other mechanisms in BEPS, such as the one proposed by Action 12 (mandatory disclosure of tax planning arrangements) could be a solution for this type of problems.

\subsection{Tax Treaty Issues}

As we have already mentioned, according to BEPS Action 4 , the most usual scenario of base erosion and profit shifting by means of interest deduction will be a crossborder situation. If this is the case and a Tax Treaty between the States of residence of the debtor and the State of residence of the creditor applies, some issues have to be taken into account. ${ }^{44}$

A general and preliminary question deals with the compatibility of the domestic anti-abuse provisions with the Tax Treaty. This is a vexata quaestio that, in spite of the general declaration in favour of that compatibility contained in Commentary to Article 1 (paragraphs 9 and $22)$ is far from being properly solved. The recent document on BEPS Action 6 contains an interesting proposal about the inclusion of a saving clause in the OECD MC which, in our view, would be a good solution for this problem. ${ }^{45}$

\section{Notes}

ECHR, decisions: 14 Oct. 2010 (Shchockin v. Ukrania), 14 May 2013 (N.K.M. v. Hungary), 25 Jun. 2013 (Gáll v. Hungary), 2 Jul. 2013 (R.Sz.v. Hungary).

Tribunal Supremo, decisions 4 Nov. 2013, 6 Mar. 2014 and 4 Jul. 2014.

The recent document on BEPS Action 2 also deals with the interaction between domestic rules and Tax Treaties. See: OECD/G20 Base Erosion and Profit Shifting Project 'Neutralising the effects of Hybrid Mismatch Arrangements' (Action 2: 2014 Deliverable), Ch. 10.

45 In its recommendation about 'Application of tax treaties to restrict a Contracting State's right to tax its own residents', proposes the addition of the following para. 3 to Art. 1 of the OECD MC: '3. This Convention shall not affect the taxation, by a Contracting State, of its residents except with respect to the benefits granted under paragraph 3 of Article 7 , paragraph 2 of Article 9 and Articles 19, 20,23, 24 and 25 and 28.' See OECD/G20 Base Erosion and Profit Shifting Project 'Preventing the Granting of Treaty Benefits in Inappropriate Circumstances' (Action 6: 2014 Deliverable), Section A. 
The first question refers to the consistency of the domestic provisions limiting the deductibility of interest with the arm's length principle and more precisely, with Article 9.1 of the OECD MC, as far as this provision refers to related parties and to "conditions are made or imposed in their commercial or financial relations which differ from those which would be made between independent enterprises, than any profits which would, but for those conditions, have accrued to one of the enterprises, but by reason of those conditions, have not so accrued, may be included in the profits of that enterprise and taxed accordingly'.

The OECD MC Commentary to Article 9.1, in its paragraph 3 a) states that this article 'does not prevent the application of national rules on thin capitalization, insofar as their effect is to assimilate the profits of the borrower to an amount corresponding to the profits which would have accrued in an arm's length situation'.

In this respect, the Dutch High Supreme Court (Hobe Raad) in its decision 21 September 2011 held that the domestic provision on thin capitalization was consistent with Article 9 of the relevant Tax Treaty. Commenting this decision, Kemmeren also shares this view on the consistency, because the Dutch rule refers to the debt/ equity ratio of the group and Article 9 of the Tax Treaty refers to 'conditions of a transaction' which refers to the individual loan between two related parties. ${ }^{46}$

Taking into account the OECD MC Commentary above mentioned which refers to 'the profits of the borrower', we think that an anti-abuse provision denying the deductibility of interest can be consistent with Article 9.1 of the OECD MC, because an artificial loan between related parties can be considered a transaction which would have never taken place between independent parties and therefore, the tax base of the borrower does not reflect the profits that would have been obtained under arm's length conditions.

In our view, another type of provisions such as the ones which limit the amount of the interest deductible according to a 'ceiling rule', should also be applied to related parties in a consistent way with the arm's length principle: first, it should be checked whether the interest paid is according to that principle (which means that the excess, if any, would not be deductible); second, the deductible amount should be compared to the ceiling rule (which means that the excess, if any, should not be deductible in that fiscal year but, eventually, it could be carried forward in subsequent years according to the relevant provision).

A different question arises from the bilateral adjustment provided for in Article 9.2 of the OECD MC, according to which 'The other State shall make an appropriate adjustment to the amount of the tax charged therein on those profits'.

In other words: should the creditor's State reduce the tax on the interest income if the deductible interest expense has been reduced in the State of source? In our view, the answer is clear as far as this reduction is a consequence of the arm's length principle, but it is more debatable if the reduction is the consequence of a provision which denies or limits the deductibility of the interest paid by the borrower to a related company, especially if this limitation applies as an anti-abuse provision. In this respect, it should be taken into account that OECD MC Commentary to Article 9.2 in its paragraph 4 states that the reversal of the burden of proof may not be consistent with arm's length principle; moreover, paragraph 11 dealing with MAP in order to solve the bilateral adjustments, refers that some States may deny this procedure in case of abusive transactions.

Article 11.6 of the OECD MC also contains an arm's length rule applicable to the interest paid between related parties according to which 'When the amount of interest, having regard to the debt-claim for which it is paid, exceeds the amount which would have been agreed upon the payer and the beneficial owner in absence of such relationship, the provision of this article shall apply only to the last-mentioned amount'. The excess will be taxed according to the laws of each State, which means: in the State of residence, accordingly and in the State of source without the limitation provided for in Article 11.2.

This provision is similar to the one in Article 9.2, but its effects are expressly connected to the provisions of Article 11, which means that the excessive interest income will not benefit from this article and therefore, has to do with the tax liability of the creditor (lender), but not with the borrower.

Another issue dealing with Tax Treaties is double taxation. In point III.2, we referred the risk of economic double taxation if the deduction of the interest expense is denied in one State and the related interest income is taxed in the other State. Moreover, because of the allocation rules in Article 11 of the OECD MC, there could be economic double taxation twice: first, the borrower is not allowed to deduct the interest expense and the lender is subject to tax on the related interest income by the State of residence; second, the borrower is not allowed to deduct the interest expense and the lender is subject to tax on the related interest income by the State of source.

For the time being, these situations cannot be solved within the framework of the Tax Treaty, because Article 23 $A$ and $B$ deal with legal double taxation. The OECD MC Commentary on the scope of the articles just says that if

\section{Notes}

46 E. Kemmeren, Netherlands: Thin capitalization rules are not inconsistent with DTCs and EU Law in Tax Treaty Case Law around the Globe 2013 (Series on International Tax Law, Michael Lang et al. Ed) IBFD Linde, 2014. 
two States wish to solve the problems of economic double taxation, they must do so in bilateral negotiations'. In our view, in the case of related parties, bilateral adjustments under Article 9.2 would be more reliable, although the difficulties above mentioned should be considered.

The non-discrimination clause set out in Article 24.4 of the OECD MC should also be taken into account when implementing limitations to the deductibility of interest, as far as according to that provision. 'Interest paid shall be deductible under the same conditions as if they had been paid to a resident of the first-mentioned State' which means that a provision limiting the deductibility of interest only if this interest is paid to a non-resident company should be considered in breach of the relevant Tax Treaty. 